\title{
HIGH-TEMPERATURE HEAT CONTENTS AND ENTROPIES OF CERIUM DIOXIDE AND COLUMBIUM DIOXIDE
}

By E. G. King and A. U. Christensen

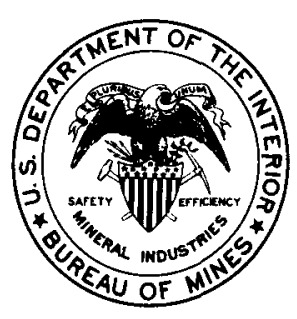

UNITED STATES DEPARTMENT OF THE INTERIOR BUREAU OF MINES 


\section{DISCLAIMER}

This report was prepared as an account of work sponsored by an agency of the United States Government. Neither the United States Government nor any agency Thereof, nor any of their employees, makes any warranty, express or implied, or assumes any legal liability or responsibility for the accuracy, completeness, or usefulness of any information, apparatus, product, or process disclosed, or represents that its use would not infringe privately owned rights. Reference herein to any specific commercial product, process, or service by trade name, trademark, manufacturer, or otherwise does not necessarily constitute or imply its endorsement, recommendation, or favoring by the United States Government or any agency thereof. The views and opinions of authors expressed herein do not necessarily state or reflect those of the United States Government or any agency thereof. 


\section{DISCLAIMER}

Portions of this document may be illegible in electronic image products. Images are produced from the best available original document. 


\section{HIGH-TEMPERATURE HEAT CONTENTS AND ENTROPIES OF CERIUM DIOXIDE AND COLUMBIUM DIOXIDE}

By E. G. King and A. U. Christensen

By E. King and A. U. Christensen 
This publication has been cataloged as follows:

\section{King, Edward G}

High-temperature heat contents and entropies of cerium dioxide and columbium dioxide, by E. G. King and A. U. Christensen. [Washington] U.S. Dept. of the Interior, Bureau of Mines [1961]

6 p. illus., tables, $26 \mathrm{~cm}$. (U.S. Bureau of Mines. Report of investiqations, 5789)

Based on work done in cooperation with the Office of Naval Research, U.S. Dept. of the Navy.

Bibliographical footnotes.

1. Cerium dioxide. 2. Columbium dioxide. 3. Entropy. I. Christensen, A U joint author. II. Title. (Series)

TN23.U7 no. $5789 \quad 622.06173$

U.S. Dept. of the Int. Library. 


\section{CONTENTS}

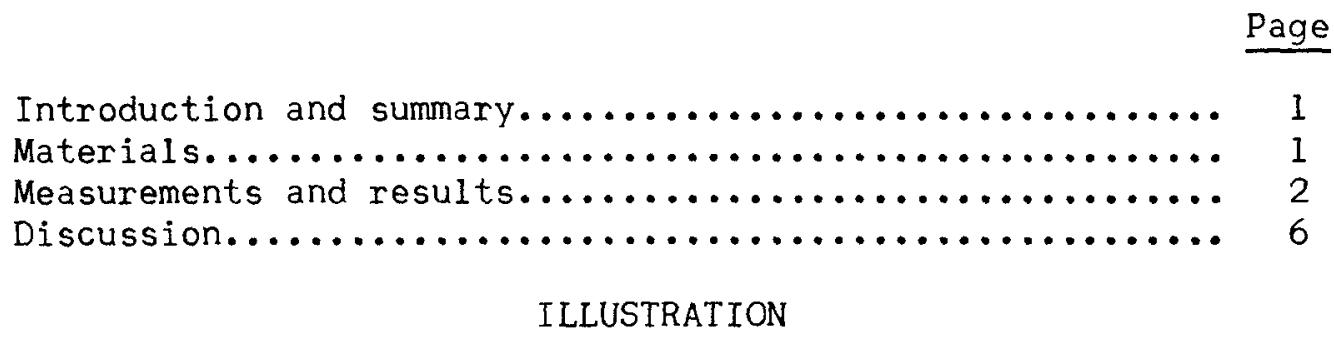

Fig.

1. Heat contents of cerium dioxide and columbium dioxide above $298.15^{\circ}$

TABLES

1. Heat contents above $298.15^{\circ} \mathrm{K}$. (measured values)..... 2

2. Heat contents and entropies above $298.15^{\circ} \mathrm{K}$.

(smooth values).......................... 4 


\title{
HIGH-TEMPERATURE HEAT CONTENTS AND ENTROPIES OF CERIUM DIOXIDE AND COLUMBIUM DIOXIDE
}

\author{
by
}

\author{
E. G. King $2 /$ and A. U. Christensen 3 /
}

\section{INTRODUCTION AND SUMMARY}

This report contains experimentally determined heat-content values for cerium dioxide and Columbium (niobium) dioxide in the temperature range from 2980 to $1,8000 \mathrm{~K}$. There are no previous similar data for Columbium dioxide, and those for cerium dioxide have an upper limit of $3730 \mathrm{~K}$.

The heat-content and corresponding entropy-increment data are presented in tabular form. Equations were derived to represent the heat contents and heat capacities.

The data for cerium dioxide are entirely regular, but those for columbium dioxide show two previously unreported anomalies at $1,090^{\circ}$ and $1,200^{\circ} \mathrm{K}$.

\section{MATERIALS}

Columbium dioxide was prepared from high-purity columbium pentoxide obtained from Fansteel Metallurgical Corp. Small batches of the pentoxide were reduced in hydrogen for 4 hours at $950^{\circ}$ to $1,000^{\circ} \mathrm{C}$., and then combined and given 4 hours more treatment in hydrogen at the same temperature. The completeness of the reduction reaction was demonstrated by heating part of the product in hydrogen at $1,450^{\circ} \mathrm{C}$. and observing that there was no change in weight. Analysis of the product by reconversion to the pentoxide indicated 99.90 percent columbium dioxide. Analysis by dissolving, precipitating the columbium as hydroxide, and igniting to constant weight showed virtually 100 percent columbium dioxide. The $x$-ray diffraction pattern matched that of Brauer, 4 who prepared his sample similarly.

1 Work on manuscript completed October 1960.

2) Project leader, Berkeley Thermodynamics Laboratory, Bureau of Mines, Berkeley, Calif.

3) Physical chemist, Berkeley Thermodynamics Laboratory, Bureau of Mines, Berkeley, Calif.

4 Brauer, G., Die Oxyd des Niobs: Ztschr. anorg. allgem. Chem., vol. 248, 1941 , p. 1. 
Cerium dioxide having a claimed purity of $99.9+$ percent was obtained from the Lindsay Chemical Division of American Potash \& Chemical Corp. It was used without treatment, except heating at 1,050 $\mathrm{C}$. for 1 hour.

\section{MEASUREMENTS AND RESULTS}

The high-temperature heat-content calorimeter was described previously. Platinum-rhodium capsules, whose heat contents were determined in separate experiments, were used to hold the oxide samples. After the capsules were filled with the oxides, they were sealed gastight by platinum welding.

The heat contents are expressed in defined calories ( 1 calorie = 4.1840 absolute joules) per mole. Molecular weights were taken as 172.13 grams for cerium dioxide and 124.91 grams for columbium dioxide. The sample sizes were 15,690 grams of cerium dioxide and 8.673 grams of columbium dioxide (both corrected to vacuum).

The measured heat-content values are listed in table 1 and shown in figure 1. The precision uncertainty in these values is less than 0.2 percent.

TABLE 1. - Heat contents above $298.15^{\circ} \mathrm{K}$. (measured values)

\begin{tabular}{|c|c|c|c|c|c|}
\hline $\mathrm{T}, \circ \mathrm{K}$. & $\begin{array}{c}\mathrm{H}_{\mathrm{T}}-\mathrm{H}_{298.15} \\
\mathrm{cal} . / \mathrm{mole}\end{array}$ & $\mathrm{T}, \circ \mathrm{K}$ & $\begin{array}{c}\mathrm{H}_{\mathrm{T}}-\mathrm{H}_{298.15} \\
\mathrm{cal} . / \mathrm{mole}\end{array}$ & $\mathrm{T}, \circ \mathrm{K}$. & $\begin{array}{c}\mathrm{H}_{\mathrm{T}}-\mathrm{H}_{298.15}, \\
\mathrm{cal} . / \mathrm{mole}\end{array}$ \\
\hline
\end{tabular}

$\mathrm{CeO}_{2}$

\begin{tabular}{r|r|r|r||r|r}
\hline 400.6 & 1,575 & 897.7 & 10,330 & $1,397.1$ & 19,850 \\
500.6 & 3,230 & $1,002.5$ & 12,310 & $1,498.5$ & 21,890 \\
595.7 & 4,860 & $1,099.3$ & 14,130 & $1,598.3$ & 23,860 \\
697.2 & 6,680 & $1,196.8$ & 16,010 & $1,696.8$ & 25,860 \\
799.9 & 8,530 & $1,302.1$ & 18,000 & $1,798.3$ & 27,930 \\
\hline 399.3 & 1,460 & $1,078.9$ & 14,710 & $1,259.3$ & 18,630 \\
500.5 & 3,060 & $1,084.4$ & 14,800 & $1,300.1$ & 19,530 \\
598.7 & 4,710 & $1,089.1$ & 15,040 & $1,396.8$ & 21,430 \\
699.1 & 6,460 & $1,100.5$ & 15,340 & $1,396.9$ & 21,360 \\
800.3 & 8,330 & $1,101.8$ & 15,330 & $1,447.1$ & 22,390 \\
899.0 & 10,250 & $1,108.5$ & 15,470 & $1,497.9$ & 23,440 \\
$1,000.7$ & 12,520 & $1,124.0$ & 15,800 & $1,597.1$ & 25,420 \\
$1,001.7$ & 12,510 & $1,150.7$ & 16,440 & $1,697.8$ & 27,380 \\
$1,050.2$ & 13,760 & $1,199.1$ & 17,480 & $1,790.8$ & 29,500 \\
$1,069.9$ & 14,380 & $1,199.1$ & 17,430 & - & - \\
\hline
\end{tabular}

The heat content of cerium dioxide is a regular function of temperature over the entire measured range (298.150 to $1,800^{\circ} \mathrm{K}$. ); no anomalous behavior 5 Kelley, K. K., Naylor, B. F., and Shomate, C. H., The Thermodynamic Properties of Manganese: Bureau of Mines Tech. Paper 686, 1946, 34 pp. 


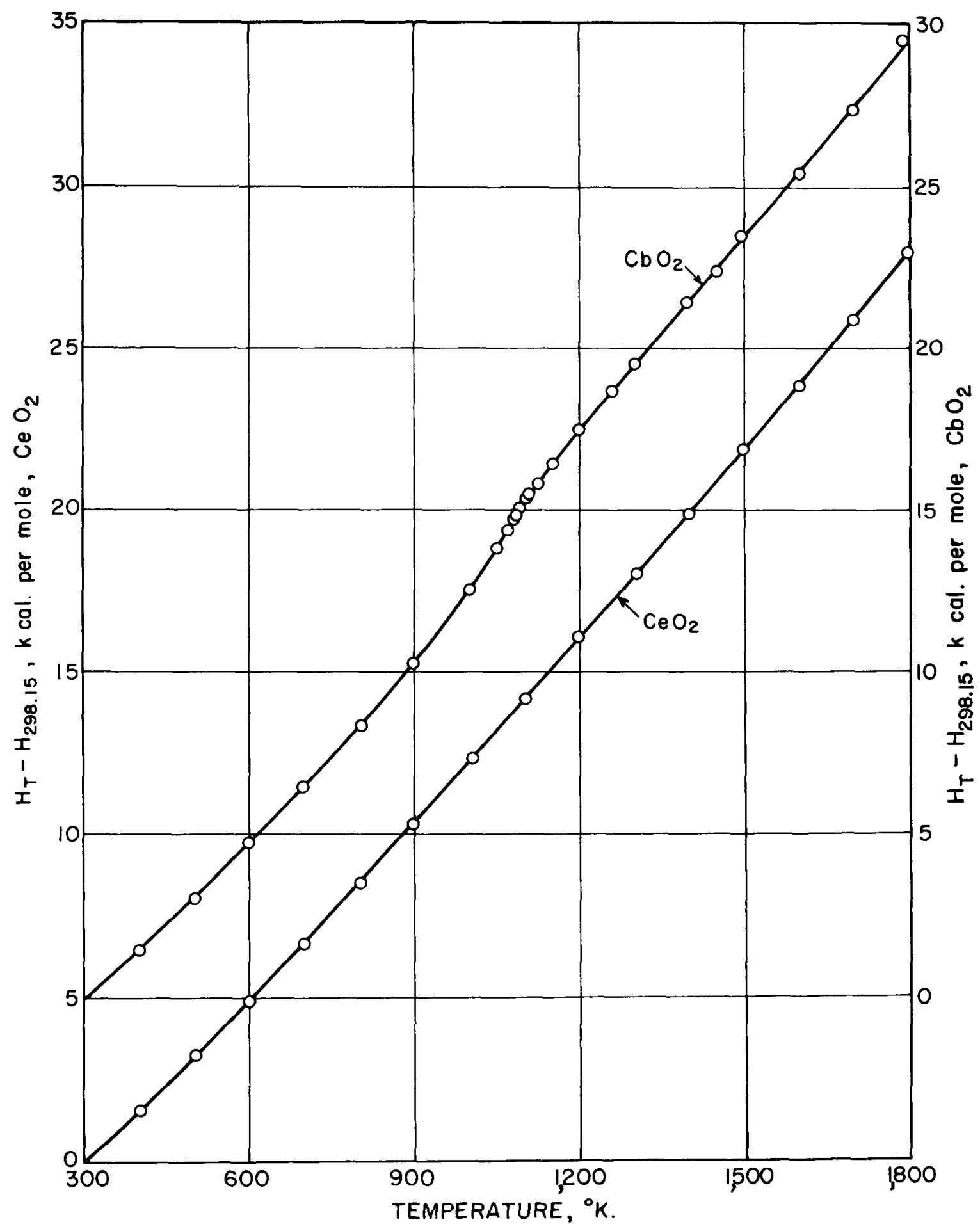

FIGURE 1. - Heat Contents of Cerium Dioxide and Columbium Dioxide Above $298.15^{\circ} \mathrm{K}$. 
of any type was observed. The heat capacity increases from 14.73 calories per degree mole at $298.15^{\circ} \mathrm{K}$. to 20.65 calories per degree mole at $1,800^{\circ} \mathrm{K}$.

Columbium dioxide has two heat-content anomalies. The first occurs at $1,090^{\circ} \mathrm{K}$. and appears to be the result of a maximum in the heat-capacity function. This anomaly is evident in figure 1. The second anomaly occurs at approximately $1,200^{\circ} \mathrm{K}$. It appears as an abrupt change in heat capacity (that is, slope of the heat-content curve). It is not evident on a plot as small as figure 1 but may be seen readily on a larger plot. No isothermal heat absorption is associated with either anomaly. The heat capacity of columbium dioxide increases from 13.74 calories per degree mole at $298.15^{\circ} \mathrm{K}$. to about 35 calories per degree mole at $1,090^{\circ} \mathrm{K}$. It then decreases rapidly to 22.2 calories per degree mole, remains substantially constant to $1,200^{\circ} \mathrm{K}$., and finally decreases abruptly to 19.85 calories per degree mole and remains substantially constant to $1,800^{\circ} \mathrm{K}$.

Table 2 gives smooth values of the heat-content and entropy increments above $298.15^{\circ} \mathrm{K}$. The latter were calculated from the former by the method of Kelley, 6 wich assures that the values are mutually consistent.

TABLE 2. - Heat contents and entropies above $298.15^{\circ} \mathrm{K}$.

(smooth values)

\begin{tabular}{r|c|c|c|c}
\hline \multirow{2}{*}{$\mathrm{T}, 0 \quad \mathrm{~K} \cdot$} & $\begin{array}{c}|c| \\
\mathrm{CeO}_{2} \\
\mathrm{cal.} / \mathrm{mole}\end{array}$ & $\begin{array}{c}\mathrm{S}_{\mathrm{T}}-\mathrm{S}_{298.15}, \\
\mathrm{cal} / \text { deg. mole }\end{array}$ & $\begin{array}{c}\mathrm{H}_{\mathrm{T}}-\mathrm{H}_{298.15} \\
\mathrm{cal} / \mathrm{mole}\end{array}$ & $\begin{array}{r}\mathrm{S}_{\mathrm{T}}-\mathrm{S}_{298.15} \\
\mathrm{cal} / \mathrm{deg} \cdot \mathrm{mole}\end{array}$ \\
\hline 400 & 1,580 & 4.55 & 1,480 & 4.26 \\
500 & 3,220 & 8.21 & 3,060 & 7.78 \\
600 & 4,940 & 11.34 & 4,730 & 10.82 \\
700 & 6,720 & 14.08 & 6,480 & 13.52 \\
800 & 8,540 & 16.51 & 8,310 & 15.96 \\
850 & - & - & 9,270 & 17.13 \\
900 & 10,380 & 18.68 & 10,280 & 18.28 \\
950 & - & - & 11,350 & 19.44 \\
1,000 & 12,250 & 20.65 & 12,500 & 20.62 \\
1,050 & - & - & 13,770 & 21.86 \\
1,090 & - & - & $15,060(\alpha)$ & $23.06(\alpha)$ \\
1,090 & - & - & $15,060(\beta)$ & $23.06(\beta)$ \\
1,100 & 14,140 & 22.45 & 15,280 & 23.26 \\
1,200 & 16,050 & 24.11 & $17,500(\beta)$ & $25.20(\beta)$ \\
1,200 & - & - & $17,500(\gamma)$ & $25.20(\gamma)$ \\
1,300 & 17,980 & 25.66 & 19,480 & 26.78 \\
1,400 & 19,930 & 27.10 & 21,470 & 28.26 \\
1,500 & 21,900 & 28.46 & 23,450 & 29.62 \\
1,600 & 23,890 & 29.74 & 25,440 & 30.91 \\
1,700 & 25,910 & 30.97 & 27,420 & 32.11 \\
1,800 & 27,960 & 32.14 & 29,410 & 33.24 \\
\hline
\end{tabular}

6 Kelley, K. K., Contributions to the Data on Theoretical Metallurgy. XIII. High-Temperature Heat-Content, Heat-Capacity, and Entropy Data for the Elements and Inorganic Compounds: Bureau of Mines Bull. 584, 1960, $232 \mathrm{pp}$. 
The heat-content values in table 2 are represented (with average deviations as indicated) by the following equations:

$$
\begin{gathered}
\mathrm{CeO}_{2}(\mathrm{c}): \\
\mathrm{H}_{\mathrm{T}}-\mathrm{H}_{298.15}=16.97 \mathrm{~T}+1.01 \times 10^{-3} \mathrm{~T}^{2}+2.54 \times 10^{5} \mathrm{~T}^{-1}-6,001 \\
\left(2980-1,8000^{\circ} \mathrm{K} ; 0.2 \text { percent }\right) . \\
\mathrm{CbO}_{2}(a): \\
\mathrm{H}_{\mathrm{T}}-\mathrm{H}_{298.15=} 11.70 \mathrm{~T}+4.78 \times 10^{-3} \mathrm{~T}^{2}+0.72 \times \mathrm{T}^{-1}-4,155 \\
\left(2980-950^{\circ} \mathrm{K} . ; 0.5 \text { percent }\right), \\
\left(\Delta \mathrm{H}_{1090}=720\right) . \\
\mathrm{CbO}_{2}(\beta): \\
\mathrm{H}_{\mathrm{T}}-\mathrm{H}_{298.15}=22.20 \mathrm{~T}-9,140\left(1,090^{\circ}-1,200^{\circ} \mathrm{K} \cdot ; 0.2 \text { percent }\right) . \\
\mathrm{CbO}_{2}(\gamma): \\
\mathrm{H}_{\mathrm{T}}-\mathrm{H}_{298.15}=19.85 \mathrm{~T}-6,320\left(1,200^{\circ}-1,800^{\circ} \mathrm{K} . ; 0.2 \text { percent }\right) .
\end{gathered}
$$

It was impossible to fit the heat-content data for $\mathrm{NbO}_{2}(\alpha)$ between $950^{\circ}$ and $1,090^{\circ} \mathrm{K}$. by the adopted type of equation. However, the given equation may be extrapolated to $1,090^{\circ} \mathrm{K}$., provided that a heat increment of 720 calories per mole is added at $1,090^{\circ} \mathrm{K}$. and treated in the same manner as if there were an isothermal heat absorption of this amount.

The corresponding heat-capacity equations are as follows:

$$
\begin{gathered}
\mathrm{CeO}_{2}(\mathrm{c}): \\
\mathrm{C}_{\mathrm{p}}=16.97+2.02 \times 10^{-3} \mathrm{~T}-2.54 \times 10^{5} \mathrm{~T}^{-2} . \\
\mathrm{CbO}_{2}(a): \\
\mathrm{C}_{\mathrm{p}}=11.70+9.56 \times 10^{-3} \mathrm{~T}-0.72 \times 10^{5} \mathrm{~T}^{-2} . \\
\mathrm{CbO}_{2}(\beta): \\
\mathrm{C}_{\mathrm{p}}=22.20 . \\
\mathrm{CbO}_{2}(\gamma): \\
C_{\mathrm{p}}=19.85 .
\end{gathered}
$$




\section{DISCUSSION}

No previous high-temperature heat-content data exist for columbium dioxide, and the two anomalies had not been reported. King]/ measured the heat capacity over the temperature range $51^{\circ}$ to $298^{\circ} \mathrm{K}$. The preceding high-temperature heat-capacity equation conforms with King's value at $298.15^{\circ} \mathrm{K}$. (13.74 calories per degree mole).

Previous heat-content data for cerium dioxide extended to only $3730 \mathrm{~K}$. and comprised only three measurements made in 1880 and 1912. Kelley $8 /$ has treated these data and adopted an average heat-capacity value of 15.1 calories per degree mole for the temperature interval $273^{\circ}$ to $373^{\circ} \mathrm{K}$. Calculation based upon the present measurements shows this value to be in error by less than 2 percent.

7 King, E. G., Low-Temperature Heat Capacities and Entropies at $298.15^{\circ} \mathrm{K}$. of Some Oxides of Gallium, Germanium, Molybdenum, and Niobium: Jour. Am. Chem. Soc., vol. 80, 1958, p. 1799.

8) Work cited in footnote $6(p .4)$. 